I.В. Шейн, П.Л. Аркушенко, С.М. Тертишнік, В.О. Кузнецов

Державний науково-дослідний інститут випробувань і сертифікаиії озброєння та військової техніки, Чернігів

\title{
ЗАГАЛЬНІ ВИМОГИ ДО СИСТЕМИ БОРТОВИХ ВИМІРЮВАНЬ ДЛЯ ПРОВЕДЕННЯ ВИПРОБУВАНЬ ОЗБРОЄННЯ ТА ВІЙСЬКОВОЇ ТЕХНІКИ РІЗНОГО ФУНКЦІОНАЛЬНОГО ПРИЗНАЧЕННЯ
}

В роботі проведено аналіз сучасного стану існуючої лабораторної бази бортових інформаційновимірювальних комплексів та реєструючих систем, які застосовуються для збору, обробки, відображення параметрів і характеристик дослідних зразків озброєння та військової техніки різного функиіонального призначення, їх складових частин з метою контролю функціонування, контролю змін параметрів та визначення помилкових дій екіпажів на об'єкти випробувань. Метою статті є аналіз сучасного стану лабораторної бази бортових інформаційно-вимірювальних комплексів і реєструючих систем та визначення загальних вимог до систем бортових вимірювань для проведення випробувань озброєння та військової техніки різного функиіонального призначення. Методом проведення дослідження є системний аналіз. Розглянуто характеристики означеного обладнання та варіанти розміщення і комутаиії у складі дослідного зразка. Визначено основні параметри для автомобільної та бронетанкової техніки, які підлягають реєстрації (вимірюванню) за допомогою бортових інформаційно-вимірювальних комплексів. Запропоновано варіант конфігурації бортової реєструючої системи на основі модулів та інтерфейсів фірми Racelogic Adas. 3 а результатами проведеного аналізу зроблено висновки щодо використання засобів реєстрації і систем бортових вимірювань, для проведення випробувань озброєння та військової техніки різного функиіонального призначення науково-дослідними лабораторіями Збройних Сил та підприємств промисловості Украӥни. Отримані результати дослідження доцільно застосовувати при обтрунтуванні загальних вимог до сучасної універсальної системи бортових вимірювань для проведення випробувань озброєння та військової техніки різного функиіонального призначення.

Ключові слова: випробування озброєння та військової техніки, загальні вимоги, інформаційновимірювальні комплекси, системи бортових вимірювань.

\section{Вступ}

Постановка проблеми. Актуальність цієї статті обумовлена євроатлантичним курсом України, в межах якого керівництво держави та сил оборони приділяє значні зусилля щодо оновлення наявного існуючого парку зразків озброєння, військової та спеціальної техніки різного функціонального призначення, особлива увага приділяється зразкам авіаційної, автомобільної та бронетанкової техніки, як новим, так і модернізованим. Для оцінки можливості застосування у Збройних Силах України та безвідмовної експлуатації яких, вимагається вимірювальний контроль параметрів роботи та тактико-технічні характеристик під час проведення випробувань. Проблемним питанням $\epsilon$ те, що більшість систем та комплексів вимірювань параметричної інформації, які експлуатуються в науково-дослідних лабораторіях бортових інформаційно-вимірювальних комплексів та реєструючих систем (БІВК РС) Збройних Сил та підприємствах промисловості України, є морально застарілими та призначені для вимірювання переважно аналогових параметрів і бінарних сигналів роботи систем на повітряних судах та не можуть бути адаптовані під інші види техніки, особливо наземної. Можливими шляхами вирішення цього питання $\epsilon$ закупівля аналогічних сучасних систем широкого спектру застосування іноземного виробництва або створення вітчизняних сучасних універсальних вимірювальних реєструючих систем.

Аналіз останніх досліджень та публікацій. В роботах [1-9] розглянуто питання застосування в якості засобів реєстрації для авіаційних комплексів пілотованих та безпілотних.

Для досягнення мети були проаналізовані технічні характеристики, принципи побудови існуючих БІВК і РС вітчизняного та перспективних систем іноземного виробництва щодо проведення вимірювань параметрів роботи систем під час проведення випробувань, як повітряних суден, так і зразків ОВТ іншого функціонального призначення, досвід підприємств оборонно-промислового комплексу держави щодо використання цих систем [10-11]. 
Метою статті $\epsilon$ аналіз сучасного стану лабораторної бази бортових інформаційно-вимірювальних комплексів і реєструючих систем та визначення загальних вимог до систем бортових вимірювань для проведення випробувань озброєння та військової техніки різного функціонального призначення.

\section{Виклад основного матеріалу}

Сучасні БІВК та РС призначені для оцінки великої кількості (сотень і навіть тисяч) взаємопов'язаних та взаємодіючих параметрів і відносяться до класу складних технічних систем.

Вивчення міжнародного та вітчизняного досвіду застосування таких систем показує, що особливої уваги потребують універсальні IBC, які можуть бути застосовані для вимірювань багатьох різноманітних параметрів, насамперед цифрових, як правило блочного типу, які можуть адаптуватися для вимірювання необхідних параметрів. Розглянемо більш детально їх характеристики, принципи побудови та можливості застосування для проведення випробувань OBT.

3 метою вироблення основних загальних вимог до перспективних БІВК та РС для проведення випробувань ОВТ різного функціонального призначення розглянемо технічні характеристики систем та комплексів бортових вимірювань, які найбільш часто використовуються при проведенні випробувань авіаційної техніки (АТ) фахівцями науководослідних (випробувальних) лабораторій Збройних Сил та підприємств оборонно-промислового комплексу України [1].

Досвід участі фахівців науково-дослідної лабораторії випробувань інформаційно-вимірювальних комплексів та реєструючих систем Державного науково-дослідного інституту випробувань і сертифікації озброєння та військової техніки (ДНДІ ВС OBT) у випробуваннях спільно з фахівцями науково-дослідних (випробувальних) лабораторій авіаційних підприємств оборонно-промислового комплексу України показує, що вибір та використання БІВК та РС для проведення випробувань досить складний і творчий процес та залежить від багатьох факторів:

- номенклатури параметрів, які потребують вимірюванням під час випробувань (аналогових, цифрових, разових команд, аудіо, відео, вібраційних, тензометричних та ін.);

- можливостей БІВК та РС щодо вимірювання визначеного діапазону вимірювань;

- визначенням необхідної частоти реєстрації параметрів (не нижче визначеної в технічному завданні);

- спроможності реєстрації визначених параметрів штатними засобами;

- можливостями реєстрації параметрів 3 похиб- кою, яка не перевищує допустимої;

- можливостями щодо встановлення БІВК та РС на борт ЛА (зразок ОВТ).

В залежності від завдань, які виконувались під час випробувань, на підприємствах промисловості використовувались різні БІВК та РС. Найбільш різноманітним та повним є оснащення випробувальної лабораторії ДП “АНТОНОВ”, тому більш детально розглянемо можливості БІВК та РС саме на цьому підприємстві та потім зупинимось на особливостях застосування засобів реєстрації під час випробувань на інших підприємствах.

В лабораторії СБВ ДП “АНТОНОВ” у відповідності до завдань випробувань для проведення вимірювань та контролю працездатності систем застосовуються як вітчизняні БІВК та РС з аналоговими принципами обробки інформації більш ранніх років виготовлення, такі як ГАММА 1101, ГАММА 3101, реєстраційно-вимірювальна система "Регата", так і сучасні, які засновані на нових фізичних принципах обробки та обміну цифрової інформації іноземного виробництва - KAM-500, “SPECTRAN", а також штатні аварійно-реєстраційні комплекси і системи.

Так, під час льотних випробувань транспортних літаків Ан-26, Ан-30 застосовувалась комплексна система вимірювань у складі: комплексів агрегативних випробувань ГАММА 1101, ГАММА 3101 різної комплектації, реєстраційно-вимірювальна система "Регата", система "SPECTRAN" для перевірки віброприскорень, а також штатний аварійноексплуатаційний реєстратор польотної інформації БУР-4-1-05 [10-11].

Для випробувань літаків типу Ан фахівцями інформаційно-вимірювальної лабораторії цього підприємства застосовувались вимірювальна система КАМ-500 та штатні бортові аварійноексплуатаційні засоби реєстрації.

Зовнішній вигляд блоків СБВ ГАММА, РВС “Регата" та КАМ-500, які застосовуються під час випробувань літаків показано на рис. 1 .

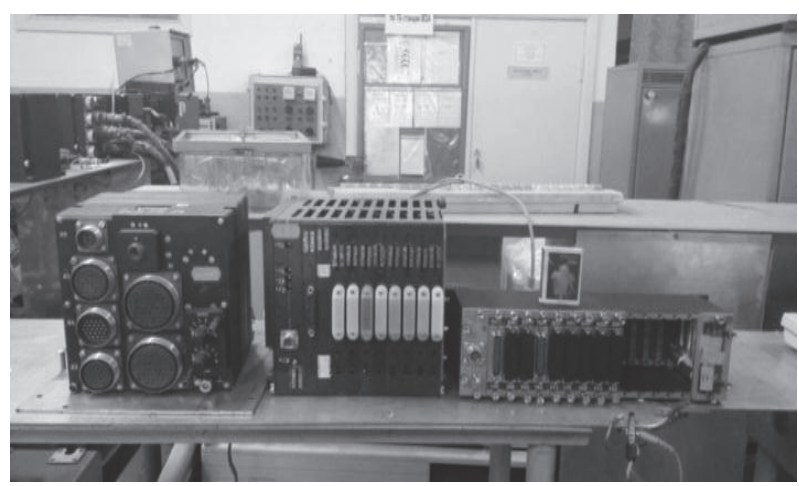

Рис. 1. Зовнішній вигляд блоків СБВ ГАММА, РВС "Регата" та КАМ-500 (зліва направо)

Джерело: [12]. 
Загальні відомості про систему КАМ-500 показано на рис. 2 [2].

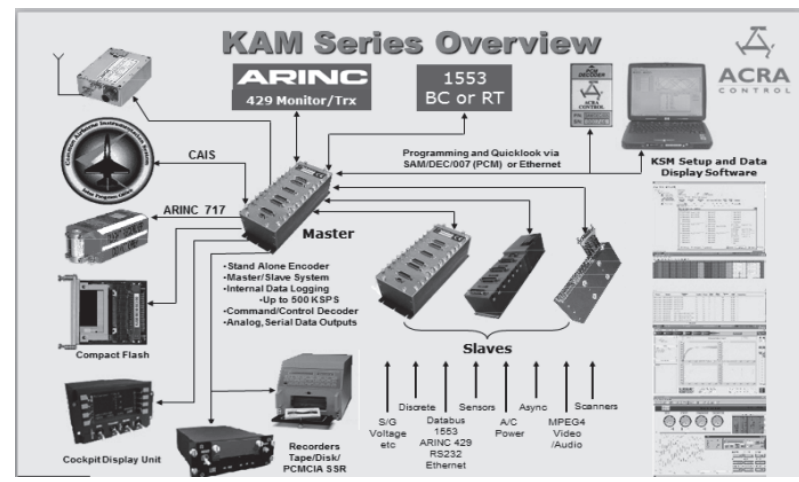

Рис. 2. Загальні відомості про систему КАМ-500

Джерело: [8].

Комплект

виробу

KAM-500

для

ДП “АНТОНОВ” був розроблений та виготовлений на підприємстві-виробнику AKRA control (Ірландія).

Приклад розміщення КАМ-500 та варіант структурної схеми на борту літака зображено на рис. 3 .

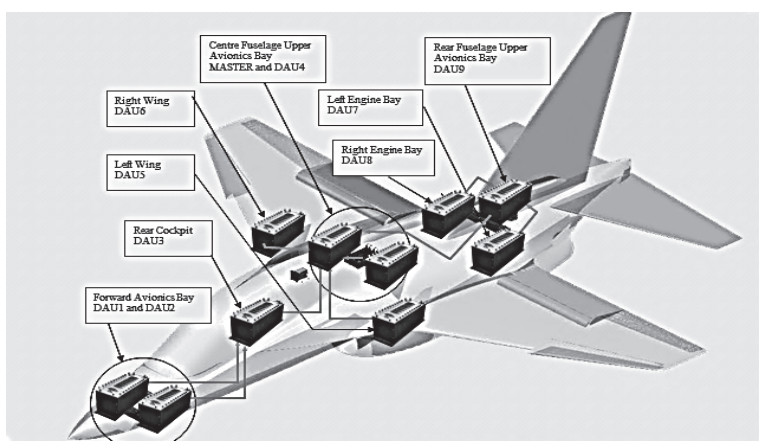

Рис. 3. Приклад розміщення системи КАМ-500 на борту літака

Джерело: [8].

На рис. 4 наведено варіант структурної схеми СБВ на базі КАМ-500 на випробуваннях літака Ан132D.

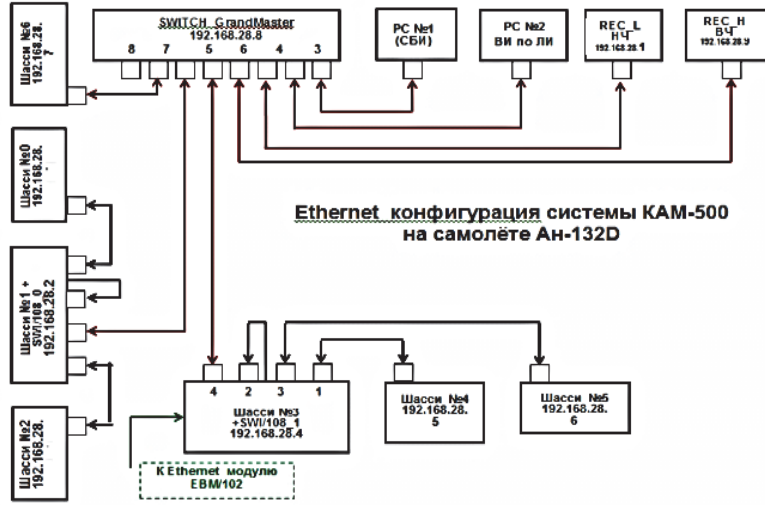

Рис. 4. Варіант Ethernet конфігурації системи КАМ-500 на літаку Ан-132D

Джерело: [12].
На інших підприємствах авіаційної промисловості, таких як ДП “410 ЦАРЗ”, ДП “Конотопський авіаремонтний завод “АВІАКОН”, АТ “Мотор Січ”, Запорізький державний авіаційний ремонтний завод "МіГремонт" та інших підприємствах використовують аналогічні засоби, за винятком КАМ-500, та додатково СБВ Російського виробництва типу МІС, а також штатні бортові аварійно-реєстраційні засоби бортових вимірювань та реєстрації і СБВ науководослідної лабораторії випробувань інформаційновимірювальних комплексів та реєструючих систем ДНДІ ВС ОВТ (ГАММА 1101, БУР-4-1), які застосовуються в якості СБВ для контролю окремих параметрів [7-8].

Таким чином, наявне у науково-дослідних (випробувальних) лабораторіях підприємств обороннопромислового комплексу України обладнання СБВ забезпечує проведення вимірювань параметрів переважно повітряних суден та деяких параметрів систем ОВТ різного функціонального призначення. Не вистачає обладнання для вимірювання насамперед цифрових параметрів роботи систем ПС, а для зразків інших видів ОВТ, насамперед автомобільного та бронетанкового.

У зв'язку з цим для обгрунтування Загальних вимог до універсальної системи бортових вимірювань для проведення випробувань озброєння та військової техніки різного функціонального призначення, насамперед бронетанкової та автомобільної техніки, що останнім часом найбільш актуально, доцільно розглянути принципи побудови, характеристики універсальних перспективних БІВК РС.

Вивчення міжнародного та вітчизняного досвіду застосування таких систем показує, що особливої уваги потребують РС, які побудовані за принципами роботи систем типу VBOX 3i RTK виробництва RACELOGIC ADAS (Німеччини і Великобританіï) та можуть бути застосовані для вимірювань багатьох різноманітних параметрів, насамперед цифрових [3; 13-15]. Розглянемо більш детально іiі характеристики, принципи побудови та можливості застосування для проведення випробувань ОВТ різного призначення.

Сучасні системи, що використовуються для випробування насамперед автомобілів, являють собою вимірювальні комплекси, що включають в себе модулі для підключення датчиків, перетворення аналогових сигналів в цифрову форму, зберігання отриманої інформації в цифровому вигляді і зв'язку з зовнішніми комп'ютеризованими пристроями. Зазначені модулі можуть бути окремими, а можуть I інтегровані в єдиний блок.

Системи VBOX застосовує кожен великий виробник автомобілів у світі для випробування продукції. Зображення реєстратора VBOX 3i RTK на рис. 5. 


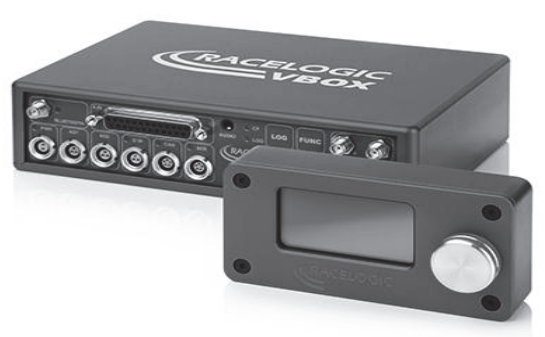
Рис. 5. Реєстратор VBOX 3i RTK
системи RACELOGIC ADAS Джерело: [11].

VBOX 3i RTK - це версія реєстратора даних 3 подвійною антеною VBOX 3 i $з$ підтримкою RTK, яка може використовуватися разом 3 диференціальною базовою станцією RTK для отримання точності позиціонування менше $2 \mathrm{~cm}$.

Цей реєстратор даних поєднує в собі всі переваги здвоєної антени GPS-налаштування із супутниковим відстеженням ГЛОНАСС і може бути використаний у будь-якій кількості випробувань автомобіля, де позиційна точність та повторюваність мають найбільше значення.

VBOX 3i RTK $є$ ключовим блоком збору даних тестових систем RACELOGIC ADAS для вимірювання відстані пройденої транспортним засобом, часу до зіткнення, положення в смузі руху з точністю менше $2 \mathrm{~cm}$.

Подвійна антена VBOX 3i RTK реєстратора даних GPS забезпечує:

- точність позиціонування за допомогою базової станції RTK;

- вимірювання кута ковзання, кута нахилу та швидкість повороту з частотою 100 Гц;

- відстеження удвічі більше супутників за допомогою GPS та ГЛОНАСС;

- дуже низьку затримку: 8,5 \pm 1 мс;

- 4 х 24 - бітові диференціальні аналогові вхідні канали з діапазоном входу $\pm 50 \mathrm{~B}$;

- цифровий вхід гальмо / тригера події.

VBOX 3i RTK можна з'єднуватися з широким спектром модулів VBOX, телеметричними системами, дисплеями та забезпечувати:

- одночасну реєстрацію до 16 каналів параметрів автомобіля по інтерфейсу CAN;

- відображення результатів у режимі реального часу через USB або Bluetooth з'єднання;

- формування голосових аудіо позначок за допомогою мікрофона;

- запис даних на карту пам'яті;

- налаштування користувачами умов ведення журналу;

- живлення від джерела у широкому робочому діапазоні - від 7 до $30 \mathrm{~B}$.

Можливості вводу та виведення даних реєстратора зображено на рис. 6 .

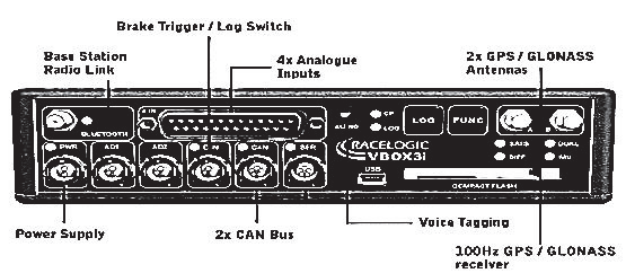

Рис. 6. Можливості вводу та виведення даних реєстратора VBOX 3i RTK

Джерело: [11].

Реєстратор має наступні можливості щодо підключення:

1) входів:

- двох антен GPS та GLONASS. Перша антена для виміру параметрів часу, швидкості, відстані та положення. Друга антена для виміру параметрів кута ковзання, кроку або кута;

- нахилу (залежно від орієнтації антени);

- двох інтерфейсів шини даних CAN. Перший для підключення до шини СAN модулів RACELOGIC таких як TC8 (модуль термопар) та FIM03 (модуль введення лічильника та імпульсів). Другий інтерфейс шини CAN для реєстрування до 16 сигналів CAN з іншого джерела CAN (наприклад, транспортної шини CAN, лазерних датчиків висоти або датчика керма та інших);

- курку педалі гальма для фіксування початку гальмування;

- чотирьох аналогових входів 3 аналоговими перетворювачами, напругою живлення 5В та частотою опитування від 100 до 500 Гц;

- мікрофону для запису голосових повідомлень тривалістю до 30 секунд з синхронізацією по GPS даним;

- джерела живлення 7 до 30 В постійного струму.

2) виходів:

- одного порту CAN шини, який використовується для виведення параметрів VBOX GPS - 12 каналів із підключених модулів вводу або внутрішніх каналів AD;

- роз'ємів RS232, USB, Bluetooth, які використовуються для конфігурації VBOX, виведення даних GPS в реальному часі, підключення до системи радіотелеметрії та моніторингу даних тесту на ПК;

- двох цифрових виходів;

- двох аналогових виходів 3 напругою від 0 до 5 В постійного струму з роздільною здатністю 76 мкВ на біт.

Інформація на CF - картку (об’ємом до 32 ГБ) реєструється у текстовому форматі. Тривалість запису залежить від ємності флеш-карти, частоти запису, кількості каналів та умов ведення журналу.

VBOX 3i RTK реєстратор сумісно 3 універсальними модулями введення RACELOGIC VBOX або безпосередньо з шини CAN транспортного засобу за 
допомогою бази даних RACELOGIC Vehicle CAN може вимірювати зі швидкістю 100 проб на секунду наступні основні параметри:

- частота обертів двигуна;

- температура систем двигуна та трансмісії від штатних датчиків автомобіля;

- температура систем (агрегатів) автомобіля та елементів конструкції від під'єднаних датчиків температури (термопар);

- час розгону автомобіля до визначеної швидкості;

- швидкість руху автомобіля;

- час гальмування автомобіля до повної зупинки;

- відстань розгону автомобіля;

- відстань пройденого шляху;

- відстань гальмування;

- час UTC;

- просторове положення/координати (довгота, широта) автомобіля;

- курс руху;

- бокова швидкість автомобіля;

- повздовжня швидкість;

- вертикальна швидкість;

- бокове прискорення;

- повздовжнє прискорення;

- вертикальне прискорення;

- кут ковзання,

- кут тангажу;

- кут нахилу (крену);

- кут повороту рульового колеса;

- поворотний момент рульового колеса;

- параметри штатних датчиків автомобіля 3

CAN шини;

- параметрів від штатних датчиків швидкості обертів коліс АВС, датчиків частоти обертів, датчиків витрати пального;

- напрямок руху;

- тиск (зусилля) на органи керування (педалі);

- час початку та завершення гальмування;

- час розгону;

- час проходження по маршруту;

- час відгуку автомобіля на дію органів керування;

- напругу живлення бортової мережі автомобіля;

- параметри зусиль елементів конструкції від тензометричних датчиків;

- витрати палива та інші параметри, які можуть задаватися програмно оператором програмноапаратного комплексу разом з частотою опитування.

Таким чином, провівши аналіз існуючої лабораторної бази IBК та РС вітчизняного виробництва та можливостей перспективних систем іноземного виробництва з урахуванням потреб в вимірюванні необхідних параметрів роботи систем ОВТ можна сформулювати основні Загальні вимоги до цій системи:

1) Цільове призначення системи.

Інформаційно-вимірювальна система реєстрації параметрів ОВТ різного функціонального призначення призначена для збору, обробки, відображення параметрів роботи систем ОВТ та їх складових (систем) під час випробувань

2) Склад системи.

До складу інформаційно-вимірювальної системи повинні входити:

- універсальна вимірювальна система реєстрації даних з навігаційною системою типу GPS;

- аналого-цифровий перетворювач;

- модуль вимірювання швидкості та пройденого шляху зразка OBT;

- модулі (блоки) для підключення датчиків аналогових, цифрових, параметрів;

- модулі (блоки) для підключення тензометричних датчиків;

- швидкісні шини, шлюзи CAN, дротові та бездротові лінії обміну інформації;

- датчики: зусиль натиснення на гальмову важіль; частоти обертання коліс; оптичний вимірювання швидкості; прискорень та кутових швидкостей; температури (термопар); тензометричні; вібрації; витрати палива; тиску; система вимірювання повороту керма;

- блок розподілу живлення;

- програмно-апаратний комплекс - ПЕОМ зі спеціалізованим програмним забезпеченням (для обробки та аналізу зареєстрованої інформації).

Дозволяється виконання окремих модулів (інтерфейсів) в одному за умови виконання ним функцій всіх об'єднуємих модулів.

3) Основними спеціальними функціями системи $\epsilon$ вимірювання параметрів зразка OBT та їх складових (систем) підчас випробувань з метою:

- отримання в процесі випробувань вимірювальної інформації, необхідної для оцінювання (перевірки) характеристик зразка ОВТ та подальшого його удосконалення;

- проведення експериментальної оцінки якісних механічних характеристик автомобільного i бронетанкового озброєння та військової техніки та їх складових.

4) Вимоги до реєструючого обладнання.

Універсальна вимірювальна система реєстрації даних 3 можливістю прийому GPS-сигналу з основними характеристиками - мати для реєстрації одночасно:

- 16 каналів CAN автомобілю (броне об'єкту);

- чотири 24-бітних диференціальних аналого-

вих вхідних канали з вхідним діапазоном $\pm 50 \mathrm{~B}$;

- вхід тригеру гальм;

- вихідний роз'єм RS-232 для налаштування ре- 
єстратора та виводу даних GPS в реальному часі;

- вихідний роз'єм USB для налаштування ре-

єстратора та виводу даних в реальному часі з часто-

тою 100 Гц на ПК;

- 2 аналогових виходи для використання додаткового обладнання для реєстрації даних (діапазон вихідної напруги складає від 0 до 5 В постійного струму з розрішенням 76 мкВ/Біт);

-2 цифрових виходи 3 програмним налаштуванням вимірюваємих параметрів та їх рівня;

- внутрішній радіо модуль Bluetooth для налаштування та виведення даних GPS в реальному часі на ПК або реєстратор даних з частотою до 100 Гц;

- здійснювати відображення результатів в реальному часі через послідовний порт, USB або Bluetooth;

- запис даних на карту компактної флешпам'яті;

- вимірювання кутів ковзання, тангажу (або крену) та швидкості сканування при частоті дискредитації GPS-сигналу до 100 Гц;

- аналогово-цифровий перетворювач повинен забезпечувати:

- перетворення аналогових сигналів в цифрові не менш 38 вхідних каналів та передачу даних по CAN-шині;

- накопичувач інформації повинен забезпечувати зберігання інформації останніх не менше 24 годин запису;

- обладнання комутації та обміну інформацією повинно забезпечувати можливість передачі (обміну) інформацією за допомогою дротових та бездротових (CAN, GPS, USB, Bluetooth) ліній зв'язку.

Комплект поставки первинних перетворювачів (датчиків) та їх технічні характеристики уточнюються при поставці вимірювальної системи та повинні забезпечувати їх спряження 3 каналами вимірювальної системи.

Програмно-апаратні засоби обробки інформації повинні забезпечувати обробку зареєстрованої інформації, з візуальним відображенням на екрані результатів обробки у вигляді таблиць, бланків та графіків змін фізичних значень параметрів, а також документування за допомогою принтера.

До складу програмно-апаратних засобів обробки інформації повинні входити:

- комплект ліцензійного загальносистемного та спеціалізованого програмного забезпечення;

- апаратні засоби ПЕОМ типу NOTEBOOK;

- принтер кольоровий;

- комплект експлуатаційної та програмної документації.
Спеціалізоване програмне забезпечення повинно забезпечувати корегування експлуатантом циклограми та назви реєстрованих параметрів, в залежності від обсягу вхідної інформації для аналізу інформації в автономному режимі, після тесту та в режимі он-лайн.

Програмно-апаратні засоби обробки інформації можуть бути покупними виробами та надаватися разом $з$ комплектом вимірювальної системи.

\section{Висновки}

Враховуючи викладене можливо зробити наступні висновки, а саме:

1. В лабораторіях IBC вітчизняних підприємств промисловості та ЗС України у відповідності до завдань, що ставляться, при проведенні випробувань використовуються, як морально та технічно застарілі системи бортових вимірювань, принцип дії яких заснований на аналогових принципах обробки сигналів, так і сучасні універсальні цифрові системи іноземного виробництва.

2. Сучасні системи бортових вимірювань, які використовуються для вимірювання параметрів на повітряних суднах та автомобільній техніці в більшості своєму є універсальними та їх можна використовувати для вимірювання параметрів під час випробувань інших видів ОВТ.

3. Аналіз технічних характеристик та особливості використання сучасних універсальних реєстраторів даних показав, що вимірювальна система (реєстратор), яка побудована за модульним принципом:

- дозволить спростити, автоматизувати процес виконання вимірювань, мінімізувати кількість помилок, що виникають в ході їх проведення;

- модульний принцип побудови системи є універсальним та дозволить забезпечити процес вимірювань при проведенні випробувань не тільки автомобільної та броне техніки їх складових, а також здійснювати вимірювання параметрів в системах різного функціонального призначення, насамперед цифрових (статичних, динамічних характеристик об'єктів, температури, тиску, вібрацій, перевантажень та інших показників);

- дозволить скоротити час на прийняття рішення щодо доцільності постачання нових та продовження ресурсу існуючих (модернізованих) зразків різних типів ОВТ до ЗС України.

4. Отриманні результати дослідження доцільно застосовувати при обгрунтуванні загальних вимог до універсальної системи бортових вимірювань для проведення випробувань озброєння та військової техніки різного функціонального призначення.

\section{Список літератури}

1. Андрєєв К.В. Обгрунтування варіантів використання бортових інформаційно-вимірювальних комплексів та реєструючих систем під час випробувань озброєння та військової техніки різного функціонального призначення. Звіт про НДР. - Чернігів : ДНДІ ВС ОВТ, 2018. - С. 12-42. 
2. Аналіз можливостей та досвіду застосування систем бортових вимірювань для проведення випробувань безпілотних літальних апаратів / Аркушенко П. Л. та ін. // Системи управління, навігації та зв'язку. - 2020. - № 4(62). - С. 9-14. https://doi.org/10.26906/SUNZ.2020.4.009.

3. Наказ Міністерства оборони України “Правила виконання польотів безпілотними авіаційними комплексами державної авіації України № 661 від 08.12.2016 p.” - Режим доступу: https://zakon.rada.gov.ua/laws/show/z0031-17\#Text (дата звернення: 22.02.2021).

4. Наказ Міністерства економічного розвитку і торгівлі України “Про затвердження переліку галузевих нормативних документів, якими користуються промислові підприємства та організації України № 352 від 20 серпня 2012 р.” Режим доступу: https://ips.ligazakon.net/document/ME120312 (дата звернення: 22.02.2021).

5. Система бортовых измерений ГАММА-2110 [Електронний ресурс]. - Режим доступу: http://www.npopribor.ru/catalog/aviatsionnoe-priborostroenie/sistemy-bortovykh-i-nazemnykh-izmereniy/sistema-bortovykh-izmereniy-gamma2110/?sphrase_id=23031 (дата звернення: 22.02.2021).

6. Обгрунтування напрямів створення системи об'єктивного контролю сучасних безпілотних авіаційних комплексів та модернізація наземних систем обробки інформації / В. Сівак, М. Андрушко, В. Ляшенко, В. Ясько // Збірник наукових праць національної академії державної прикордонної служби України. - 2019. - № 3(81). - С. 486-504. - Режим доступу: http://periodica.nadpsu.edu.ua/index.php/military_tech/article/download/489/470/ (дата звернення: 22.02.2021).

7. Бортовые измерительные системы НПП "Мера". - Режим доступу: http://www.nppmera.ru/ (дата звернення: 22.02.2021).

8. Офіційний сайт CURTISS-WRIGHT CORPORATION. Сбор данных. Обзор системы КАM-500. - Режим доступу: https://wwwcurtisswrightds.com/products/flight-test/data-acquisition/acrakam500/ (дата звернення: 22.02.2021).

9. Андрушко М.В. Дослідження шляхів створення системи об'єктивного контролю сучасних БпАК та уніфікації наземних систем обробки інформації / М.В. Андрушко, С.В. Ратушний // Системи озброєння і військова техніка. - 2018. - № 2(54). - C. 67-76. https://doi.org/10.30748/soivt.2018.54.09.

10. Шейн І.В. Вивчення варіантів використання бортових інформаційно-вимірювальних комплексів та реєструючих систем під час випробувань озброєння та військової техніки різного функціонального призначення / I.В. Шейн, М.В. Андрушко // Збірник наукових праць Державного науково-дослідного інституту випробувань і сертифікації озброєння та військової техніки. - 2019. - № 2(2). - С. 166-170.

11. Офіційний сайт VBOXAUTOMOTIVE.CO. VBOX 3i Dual Antenna RTK High positional accuracy for ADAS Testing. - Режим доступу: http://www.vboxautomotive.co.uk / (дата звернення: 22.02.2021).

12. Кузьміч О.Є. Дослідження можливостей застосування дослідного зразка реєстратора польотних параметрів РП-24 в якості системи бортових (об’єктових) вимірювань під час випробувань зразків ОВТ. Звіт про НДР. - Чернігів: ДНДІ ВС ОВТ, 2018. - С. 11-42.

13. Цибатов В.А. Оптимизация бортовых систем сбора и обработки данных / В.А. Цибатов. - М.: Наука, 1983. - 176 с.

14. Перспективы развития бортовых регистраторов // Новости зарубежной науки и техники. - 1990. - № 2. - C. $65-68$.

15. Современные измерительные системы и их возможности (на примере продукции фирмы IMC) [Електронний pecypc]. - Режим доступу: http://www.sensorika.com/ (дата звернення: 22.02.2021).

Надійшла до редколегії 15.03.2021

Схвалена до друку 12.05.2021

\section{Відомості про авторів:}

Шейн Ігор Владиславович

науковий співробітник

Державного науково-дослідного інституту випробувань і сертифікації озброєння та військової техніки,

Чернігів, Україна

https://orcid.org/0000-0003-4640-0205

\author{
Аркушенко Павло Леонідович \\ кандидат технічних наук \\ начальник науково-дослідного відділу \\ Державного науково-дослідного інституту випробувань \\ і сертифікації озброєння та військової техніки, \\ Чернігів, Україна \\ https://orcid.org/0000-0002-1902-696X
}

\section{Тертишнік Свген Михайлович}

науковий співробітник

Державного науково-дослідного інституту випробувань і сертифікації озброєння та військової техніки,

Чернігів, Україна

https://orcid.org/0000-0003-3356-7639

\section{Information about the authors:}

\section{Ihor Shein}

Research Associate of State Scientific Research Institute of Armament and Military

Equipment Testing and Certification,

Chernihiv, Ukraine

https://orcid.org/0000-0003-4640-0205

\section{Pavlo Arkushenko}

Candidate of Technical Sciences

Chief of Scientific Research Department

of Institute of Armament and Military Equipment

Testing and Certification,

Chernihiv, Ukraine

https://orcid.org/0000-0002-1902-696X

\section{Evgen Tertushnik}

Research Associate of State Scientific Research

Institute of Armament and Military Equipment

Testing and Certification,

Chernihiv, Ukraine

https://orcid.org/0000-0003-3356-7639 
Кузнецов Владлен Олександрович

начальник науково-технічного комплексу вимірювань

Державного науково-дослідного інституту випробувань і сертифікації озброєння та військової техніки,

Чернігів, Україна

https://orcid.org/0000-0002-3156-2159
Vladlen Kuznetsov

Head of Scientific and Technical Complex

of Measurements of State Scientific Research Institute

of Armament and Military Equipment

Testing and Certification,

Chernihiv, Ukraine

https://orcid.org/0000-0002-3156-2159

\title{
ОБЩИЕ ТРЕБОВАНИЯ К СИСТЕМЕ БОРТОВЫХ ИЗМЕРЕНИЙ ДЛЯ ПРОВЕДЕНИЯ ИСПЫТАНИЙ ВООРУЖЕНИЯ И ВОЕННОЙ ТЕХНИКИ РАЗНОГО ФУНКЦИОНАЛЬНОГО НАЗНАЧЕНИЯ
}

\author{
И.В. Шейн, П.Л. Аркушенко, Е.М. Тертишник, В.А. Кузнецов
}

\begin{abstract}
В работе проведен анализ современного состояния существующей лабораторной базы бортовых информационноизмерительных комплексов и регистрирующих систем, применяемых для сбора, обработки, отображения параметров и характеристик опытных образцов вооружения и военной техники различного функционального назначения, их составных частей с иелью контроля функичонирования, контроля изменений параметров и определения ошибочных действий экипажей на объекты испьтаний. Целью статьи является анализ современного состояния лабораторной базы бортовых информационно-измерительных комплексов и регистрируюших систем и определения основных параметров систем бортовых измерений для проведения испытаний вооружения и военной техники различного функционального назначения. Методом проведения исследования является системный анализ. Рассмотрены характеристики указанного оборудования и варианты размещчения и коммутацчи в составе опытного образца. Определены основные параметры для автомобильной и бронетанковой техники, подлежащих регистрации (измерению) с помощьюю бортовых информационно-измерительных комплексов. Предложен вариант конфигурации бортовой регистрирующей системы на основе модулей и интерфейсов фирмы Racelogic Adas. C результатами проведенного анализа сделан вывод по использованию средств регистрации и систем бортовых измерений, для проведения испытаний вооружения и военной техники различного функционального назначения научно-исследовательских лабораторий Вооруженных Сил и предприятий промылиленности Украины. Полученные результаты исследования ичелесообразно применять при обосновании общчих требований к современной универсальной системе бортовых измерений для проведения испытаний вооружения и военной техники различного функиионального назначения.
\end{abstract}

Ключевые слова: испьтания вооружения и военной техники, общчие требования, информационно-измерительные комплексы, системы бортовых измерений.

\section{GENERAL REQUIREMENTS FOR THE ON-BOARD MEASUREMENT SYSTEM FOR WEAPON TESTING AND MILITARY EQUIPMENT OF DIFFERENT FUNCTIONALS}

\section{Shein, P. Arkushenko, E. Tertushnik, V. Kuznetsov}

The analysis of the current state of the existing laboratory base of onboard information and measuring complexes and recording systems used for collection, processing, display of parameters and characteristics of prototypes of armaments and military equipment of different functional purpose, their components in order to control the functioning, control of changes in parameters and determination of erroneous actions of crews on test objects. The purpose of the article is to analyze the current state of the laboratory base of onboard information and measurement systems and recording systems and determine the basic parameters of onboard measurement systems for testing weapons and military equipment for various functional purposes. The method of research is system analysis. The characteristics of the specified equipment and options for placement and switching in the prototype are considered. The main parameters for automobile and armored vehicles, which are subject to registration (measurement) with the help of onboard information and measuring complexes, are determined. A variant of the on-board recording system configuration based on Racelogic Adas modules and interfaces has been proposed. Based on the results of the analysis, conclusions were made on the use of registration means and on-board measurement systems for testing weapons and military equipment for various functional purposes of research laboratories of the Armed Forces and industrial enterprises of Ukraine. The obtained research results should be used to substantiate the general requirements for a modern universal system of onboard measurements for testing weapons and military equipment for various functional purposes.

Keywords: testing of armaments and military equipment, general requirements, information-measuring complexes, onboard measurement systems. 